\title{
馬の骨格の化學的組成に就て(第1 疑)
}

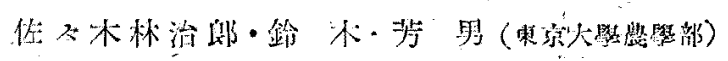

Oh the Chemical Cemposition of Horse Bones.

Rinjiro Sagaki. Yorhio SUzUKi (Faculty of Agriculture, Tokyo University)

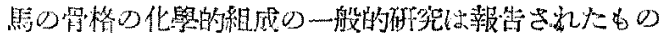

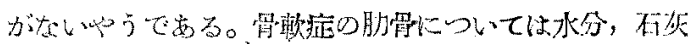

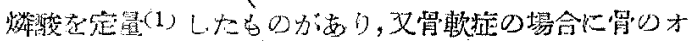

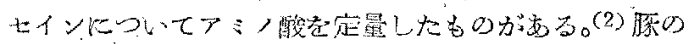

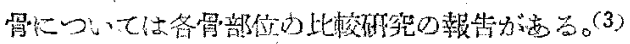

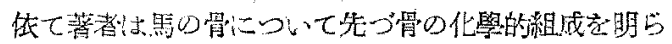

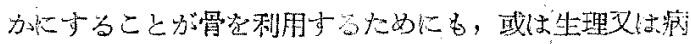

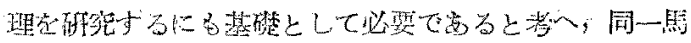

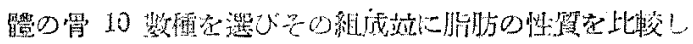

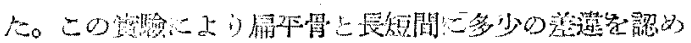

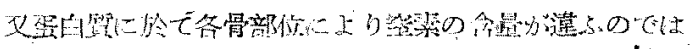

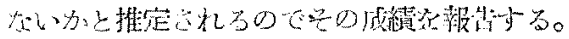

\section{實驗}

(1) 供試料

(a)窒組成の比较に用ひたもの福正號 25

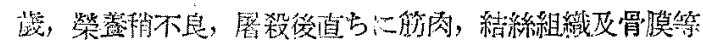

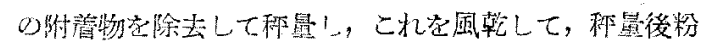

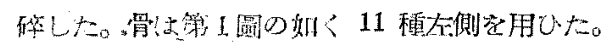

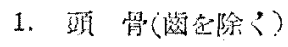

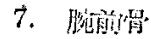
2. 下紫臂( ")

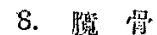

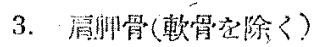
9. 股 学
4. 肪盛
10. 聯腓骨
5. 上膊骨
11. 践前骨"
6. 筧尺骨

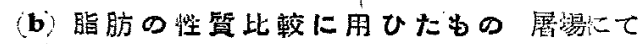

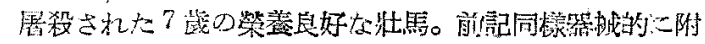

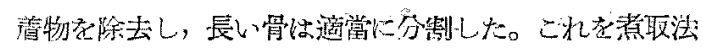

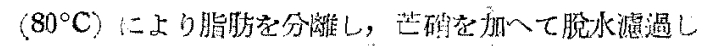

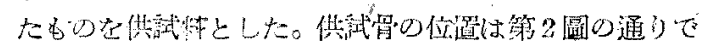

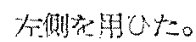

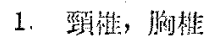 3. 肪解
6. 锩尺骨

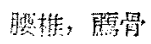
4. 臂叫骨

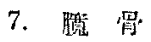

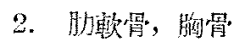
5. 上䏺罱
8. 脛腓:
(2) 分析法。

(a) 骨組 成

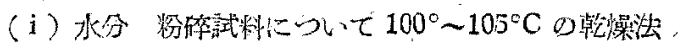
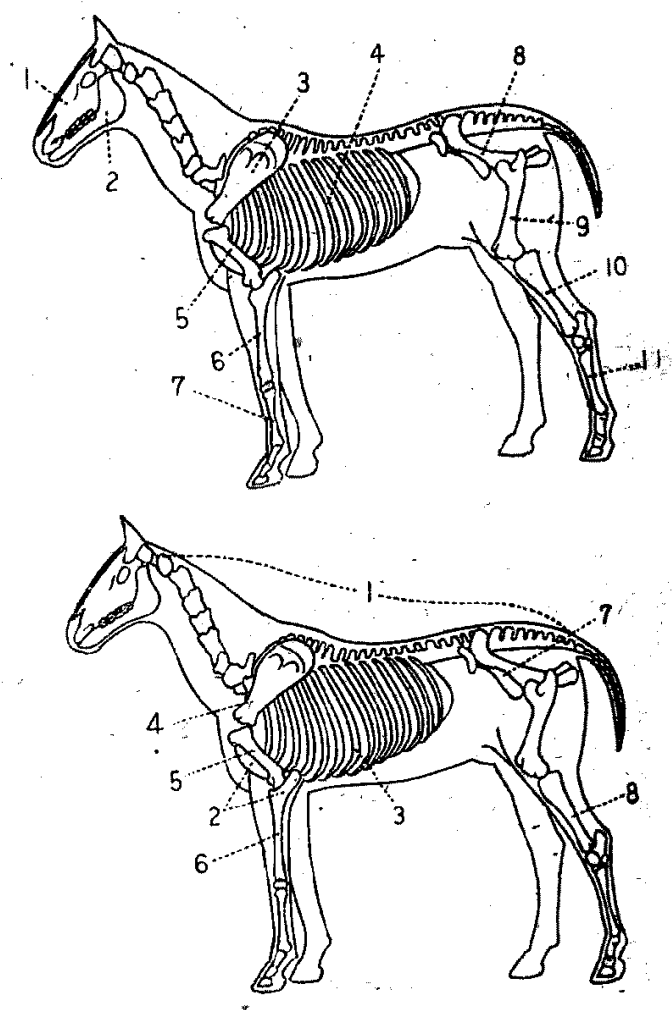

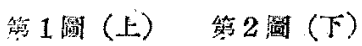

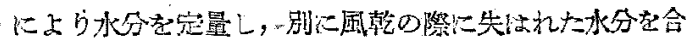
算した。

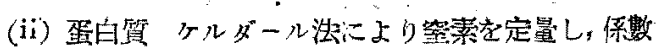
6.25 を用ひた。

(iii) 脂肪 ソックスレット法こよる。

(iv) 灰分 灰化法区上る。

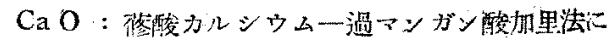
より定量し㶧。

$\mathrm{P}_{0} \mathrm{O}_{5}$ : Ammonium Phosphomolybdate $と \mathrm{~L}$ て浓澱せしめ，これにアルガリを加へて

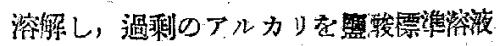
にて滴定した。(4) 
(b)脂肪の性留

(i) 屈析犁 Abbe's Refractometer 走用U $20^{\circ} \mathrm{C}$ にて浿定した。

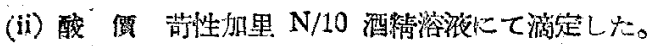

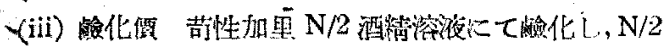

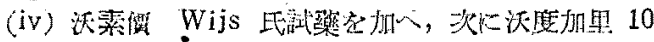

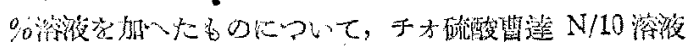
比滴定した。

\section{(3) 葢驗結果}

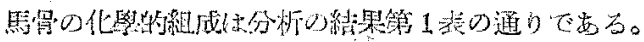

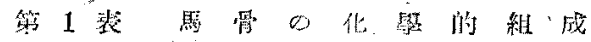

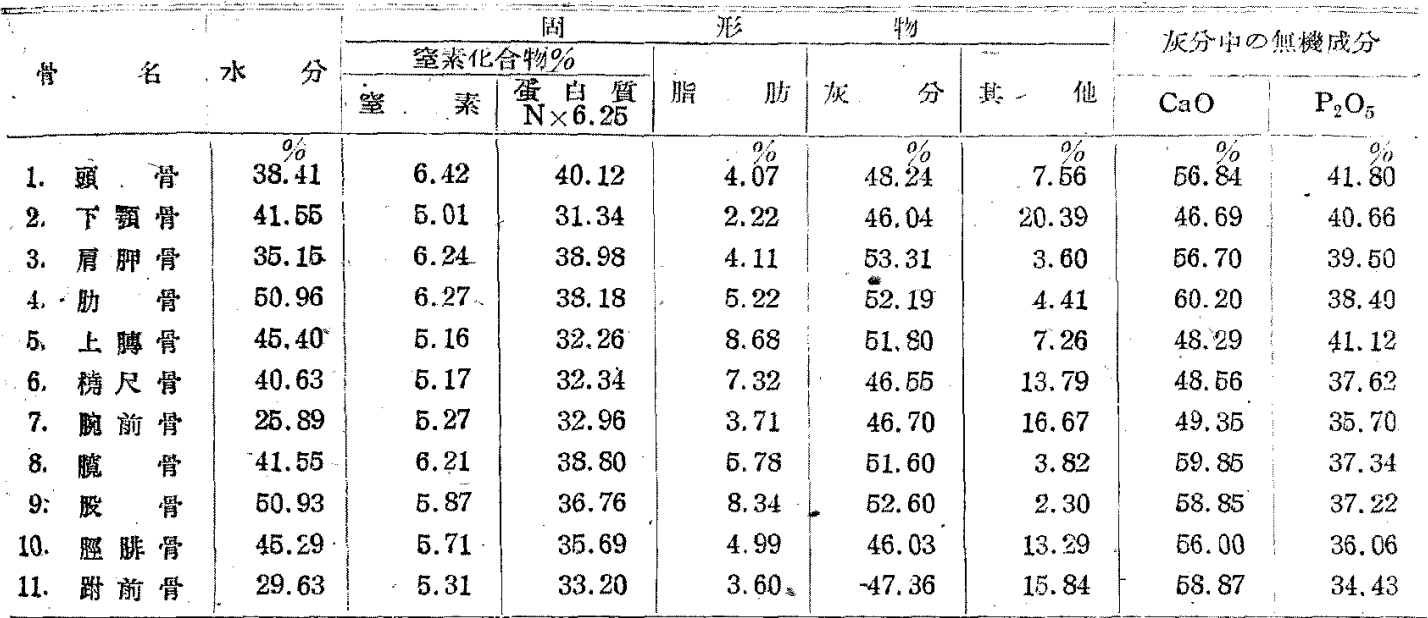

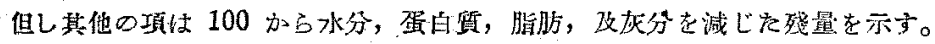

脂肪の性質は分析の結果第 2 溒の通りである。 管 2 表 馬骨の脂肪性犋

\begin{tabular}{|c|c|c|c|c|c|c|}
\hline 垌 & & 名 & $\begin{array}{l}\text { 属折新 } \\
20^{\circ} \mathrm{C}\end{array}$ & 酸" & 鰩化儥 & 沃素覞 \\
\hline 1. 㹵 & 椎, & 淗椎, & 1.4704 & 2.16 & 211.99 & 83.7 \\
\hline 2; 筙 & 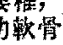 & 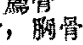 & 1.4721 & 9.66 & 232.22 & 83.7 \\
\hline 3. 肋 & & 管 & 1.4719 & 10.92 & 226.00 & 79.5 \\
\hline 4. 膺 & 脚 & 管 & 1.4708 & 25.73 & 229.92 & 87.9 \\
\hline 5. $上$ & 上膞 & 管 & 1. 4663 & 19.39 & 204.02 & 102.4 \\
\hline 6. 穘 & 喜 尺 & 管 & 1.4672 & 8.96 & 200.09 & 90.3 \\
\hline 7. 㬴 & & 骨 & 1.4709 & 30.37 & 229.14 & 71.0 \\
\hline 8. 㺟 & 苔 腓 & 管 & 1.4663 & 37.99 & 199.04 & 92.2 \\
\hline
\end{tabular}

\section{考察}

（1）化學的組成 各霆の骨の中て水分の最多受、

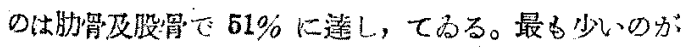

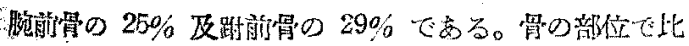

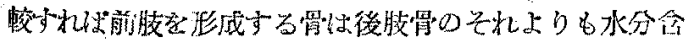

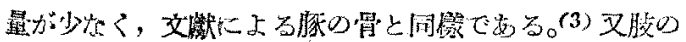

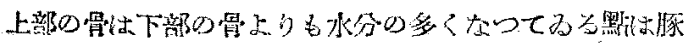

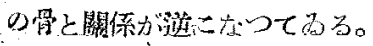

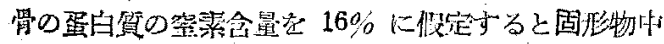

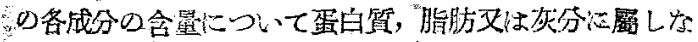

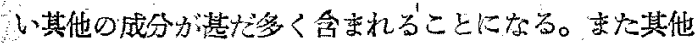

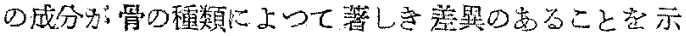
す。然しこの間題は骨の蛋白質の空素含星を $16 \%$ と假

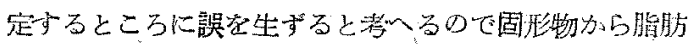

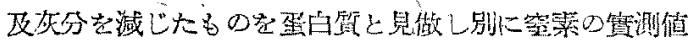

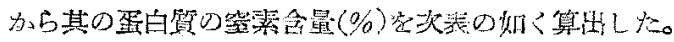

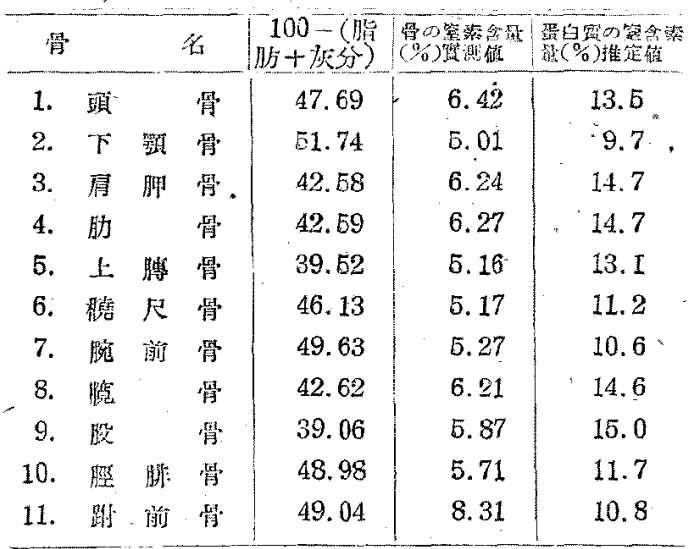

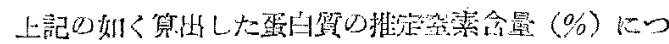

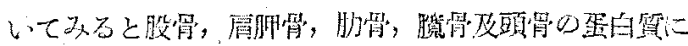

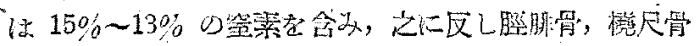

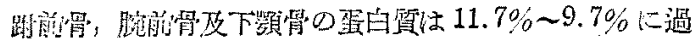

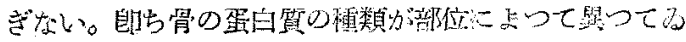


ることが推定されるる。但しこの計算には分析上胃の脂肪

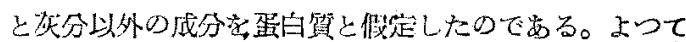

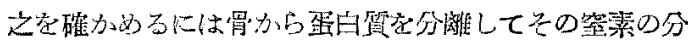
布定定曒与る必要がある。

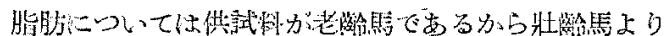

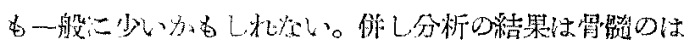

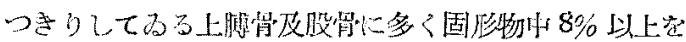

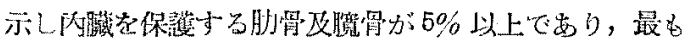

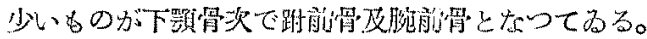

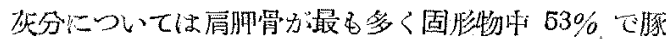
の骨(3)の52.650\% に似て名る。

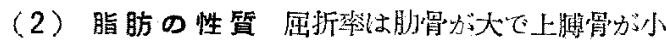
であつて虛本骨が大となつてるる。

酸僄が汾析上高くなつてるるのは脂肪の抽出まで室湍

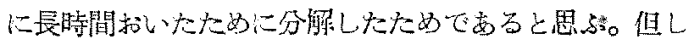

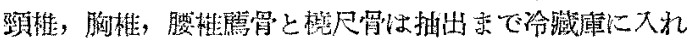
て为いたのて酸傊方低い。

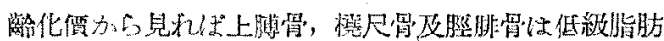

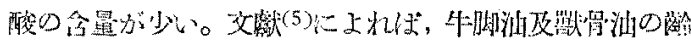

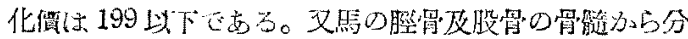

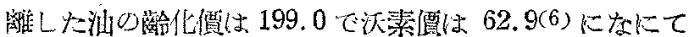

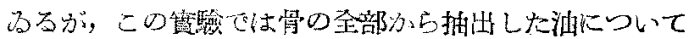

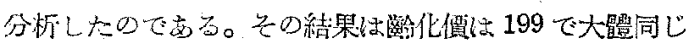

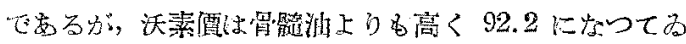

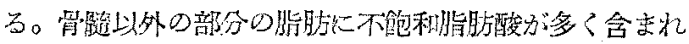

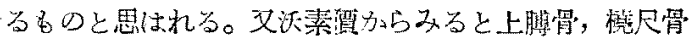

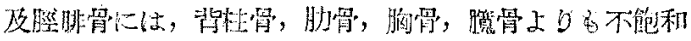
脂肪般が多くふく要れる。

\section{結論}

(1) 水分含量は剖後肢形成骨心的て上部上り下部二 至るに织つて次第に少くなつてるる。

（2）蛋白質は推定に上れば各骨部值によつて空素の

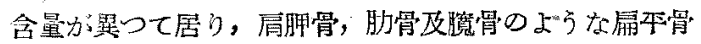
に多くふくまれ且つ大縣同じ組成になつていることが想

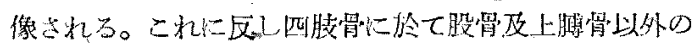

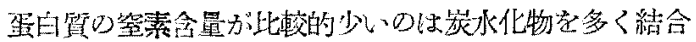

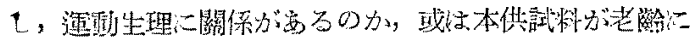

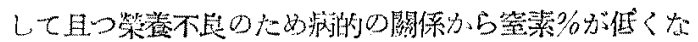
つてきるのてはないかと想像される。以上の間题は骨妃

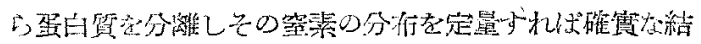
馀为得的札方。

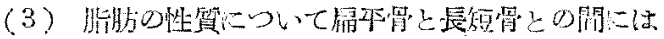

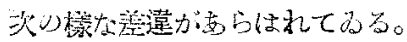

\begin{tabular}{|c|c|c|}
\hline 性質 骨 & 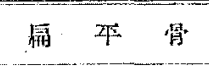 & 短 \\
\hline 風折拲 $20^{\circ} \mathrm{C}$ & $1.4704 \sim 1.4721$ & 1. $4663 \sim 1.4667$ \\
\hline 龄 化 啮 & $211 \sim 232$ & $199 \sim 204$ \\
\hline 沃素 唒 & $71 \sim 83$ & $90 \sim 102$ \\
\hline
\end{tabular}

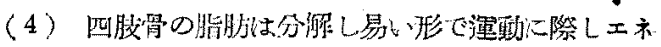
ルギーの補給をしてるることが䓡像される。

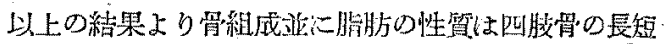

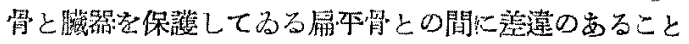

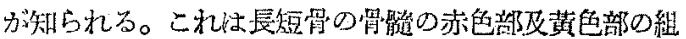

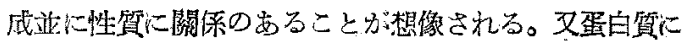
ついては学加蛋白貿を分唯し空素の分布を定量して綃

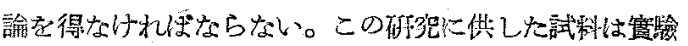

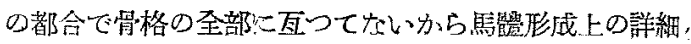
は末だ不明の點ががあるが概要の推定には十分と思ふ。

\section{要 約}

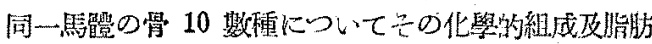
の性質を比較した結果，麻平骨と長短骨との間に多少の

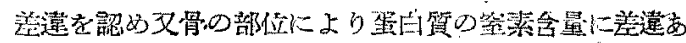
るこどを推定した。

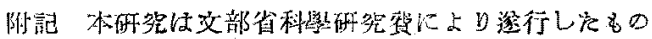

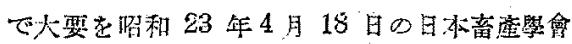

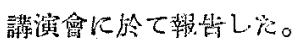

\section{文}

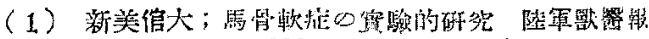
217 部，炤和 2 年 p. 668.

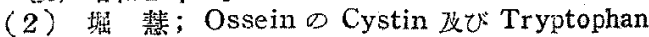
○会繁 科學 诏和 9 年 p. 265 .

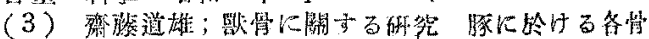

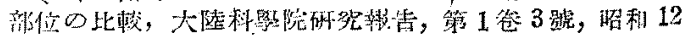
作 $\mathrm{p} .63$.

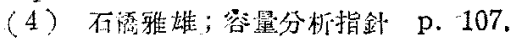

(5)上野誠一; 油脂寞驗法 p. 269.

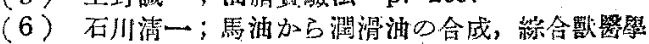

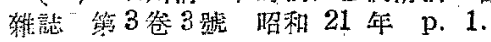

\section{Résumé}

The chemical composition of 11 kinds of bones and the chemical property of fat contained in 8 kinds of bones of same horse were determined. The results are as followos:

(1) Water contains gradually less lowuads in the bones forming both legs.

(2) Nitrogen contents of proteins are presumed to be different in many parts of bones from analytical values.

(3) Properties of fat are at clear variance with os planum between os longum-breve, and fat of legs are supposed to be easily decompos:ble, suppling kinetic energy. 